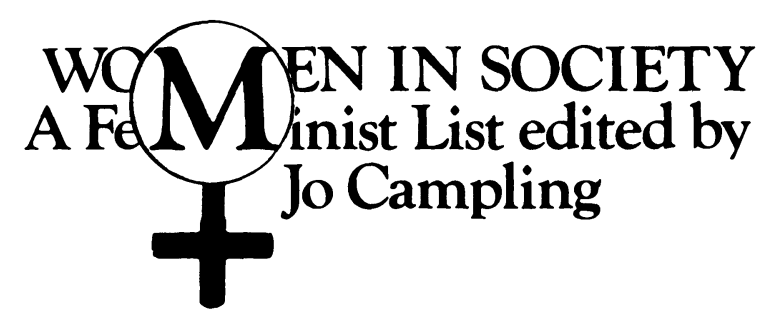

editorial advisory group

Maria Brenton, University College, Cardiff; Phillida Bunckle, Victoria University, Wellington, New Zealand; Miriam David, Polytechnic of the South Bank; Leonore Davidoff, University of Essex; Janet Finch, University of Lancaster; Jalna Hanmer, University of Bradford; Beverley Kingston, University of New South Wales, Australia; Hilary Land, University of Bristol; Diana Leonard, University of London Institute of Education; Susan Lonsdale, Polytechnic of the South Bank; Jean O'Barr, Duke University, North Carolina, USA; Arlene Tigar McLaren, Simon Fraser University, British Columbia, Canada; Jill Roe, Macquarie University, Australia; Hilary Rose, University of Bradford; Susan Sellers, Centre D'Etudes Féminines, Université de Paris; Pat Thane, Goldsmiths' College, University of London; Jane Thompson, University of Southampton; Clare Ungerson, University of Kent at Canterbury; Judy Walkowitz, Rutgers University, New Jersey, USA.

The 1970s and 1980s have seen an explosion of publishing by, about and for women. This new list is designed to make a particular contribution to this process by commissioning and publishing books which consolidate and advance feminist research and debate in key areas in a form suitable for students, academics and researchers but also accessible to a broader general readership.

As far as possible books will adopt an international perspective incorporating comparative material from a range of countries where this is illuminating. Above all they will be interdisciplinary, aiming to put women's studies and feminist discussion firmly on the agenda in subject-areas as disparate as law, physical education, art and social policy. 


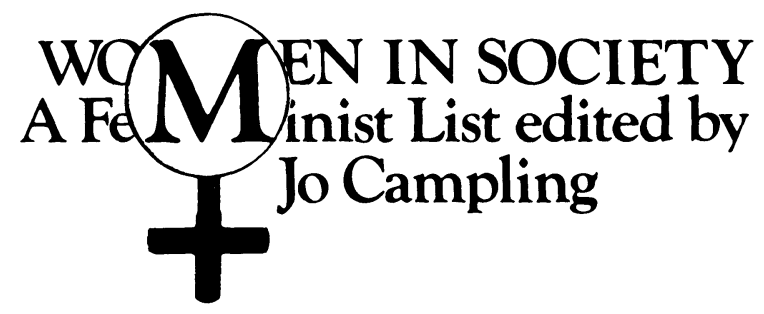

Published

Sheila Allen and Carol Wolkowitz Homeworking: myths and realities

Jenny Beale Women in Ireland: voices of change

Angela Coyle and Jane Skinner Women and Work: positive action for change

Gillian Dalley Ideologies of Caring: rethinking community and collectivism

Leonore Davidoff and Belinda Westover (editors) Our Work, Our Lives, Our Words: women's history and women's work

Emily Driver and Audrey Droisen (editors) Child Sexual Abuse: a feminist reader

Diana Gittins The Family in Question: changing households and familiar ideologies

Frances Heidensohn Women and Crime

Ursula King Women and Spirituality: voices of protest and promise

Muthoni Likimani (Introductory Essay by Jean O'Barr) Passbook Number F.47927: women and Mau Mau in Kenya

Jo Little, Linda Peake and Pat Richardson (editors) Women in Cities: gender and the urban environment

Sharon Macdonald, Pat Holden and Shirley Ardener (editors) Images of Women in Peace and War: cross-cultural and historical perspectives

Shelley Pennington and Belinda Westover A Hidden Workforce: homeworkers in England, 1850-1985

Vicky Randall Women and Politics: an international perspective (2nd edn)

Rosemary Ridd and Helen Callaway (editors) Caught Up in Conflict: women's responses to political strife

Patricia Spallone Beyond Conception: the new politics of reproduction

Taking Liberties Collective Learning the Hard Way: women's oppression and men's education

Clare Ungerson (editor) Women and Social Policy: a reader

\section{Forthcoming}

Eileen Aird and Judy Lown Education for Autonomy: processes of change in women's education Niam Baker Happily Ever After? Women's fiction in post-war Britain

Jennifer Breen Women and Fiction

Maria Brenton Women and Old Age

Joan Busfield Women and Mental Health

Ruth Carter and Gill Kirkup Women in Engineering

Lesley Ferris Acting Women: images of women in theatre

Tuula Gordon Feminist Mothers

Frances Gray Women and Laughter

Eileen Green, Diana Woodward and Sandra Hebron Women's Leisure, What Leisure?

Jennifer Hargreaves Women and Sport

Annie Hudson Troublesome Girls: adolescence, femininity and the state

Susan Lonsdale Women and Disability

Mavis Maclean Surviving Divorce: women's resources after separation

Jan Pahl Marriage and Money

Lesley Rimmer Women's Family Lives: changes and choices

Susan Sellers Language and Sexual Difference: feminist writing in France

Jane Thompson Introducing Women's Studies

Deborah Valenze The Other Victorian Women

Janet Wolff The Art of Women

Ann Woodhouse Sex, Gender and Transvestism 


\title{
A Hidden Workforce
}

Homeworkers in England, 1850-1985

\author{
Shelley Pennington \\ and \\ Belinda Westover
}

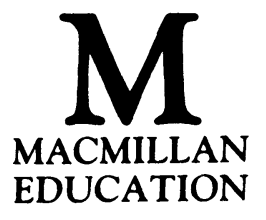


(C) Shelley Pennington and Belinda Westover 1989

Softcover reprint of the hardcover 1st edition 1989

All rights reserved. No reproduction, copy or transmission of this publication may be made without written permission.

No paragraph of this publication may be reproduced, copied or transmitted save with written permission or in accordance with the provisions of the Copyright Act 1956 (as amended), or under the terms of any license permitting limited copying issued by the Copyright Licensing Agency, 33-4 Alfred Place, London WC1E 7DP.

Any person who does any unauthorised act in relation to this publication may be liable to criminal prosecution and civil claims for damages.

First published 1989

Published by

MACMILLAN EDUCATION LTD

Houndmills, Basingstoke, Hampshire RG21 2XS

and London

Companies and representatives

throughout the world

British Library Cataloguing in Publication Data

Pennington, Shelley

A hidden workforce: homeworkers in

England, 1850-1985.-(Women in society)

1. England. Women. Home employment, 1850-

1985

I. Title II. Westover, Belinda, 1949

III. Series

331.4

ISBN 978-0-333-43297-6 ISBN 978-1-349-19854-2 (eBook)

DOI 10.1007/978-1-349-19854-2

\section{Series Standing Order}

If you would like to receive future titles in this series as they are published, you can make use of our standing order facility. To place a standing order please contact you bookseller or, in case of difficulty, write to us at the address below with your name and address and the name of the series. Please state with which title you wish to begin you standing order. (If you live outside the United Kingdom we may not have the rights for your area, in which case we will forward your order to the publisher concerned.)

Customer Services Department, Macmillan Distribution Ltd, Houndmills, Basingstoke, Hampshire, RG21 2XS, England. 
To our mothers 


\section{Contents}

List of illustrations

viii

Preface

ix

1. A woman's place is in the home 1

2. Homeworkers: work and family life 15

3. Homework and economic change, 1850-1914 30

4. Types of homework 44

5. The tailoring industry, 1850-1914 66

6. Homework as sweated labour 82

7. Legislation and trade unions 102

8. Homework, 1914-1945 126

9. Homework, 1945-1985 152

$\begin{array}{ll}\text { Notes } & 171\end{array}$

$\begin{array}{lr}\text { Select bibliography } & 182\end{array}$

$\begin{array}{ll}\text { Index } & 184\end{array}$ 


\section{List of illustrations}

1. A lower middle-class family doing homework c. $1900 \quad 20$

2. Artificial-flower-making at home 29

3. Skirt-making 35

4. Children helping with trouser-making 38

5. $\quad$ Mattress-stuffing $c$. $1890 \quad 47$

6. Cigar-making in the East End of London 48

7. Sack-making in the East End of London 53

8. Matchbox-making in the East End of London c. $1890 \quad 61$

9. Homeworker at anvil in Forge 63

10. Machinist 68

11. ) 95

12. Home and workplace! 96 


\section{Preface}

Homeworkers are most often women who work in their own homes for an outside employer. They are paid on a piece-work basis. In general they work alone but they are sometimes helped by members of the family, neighbours or friends. The work is usually unskilled and of a boring and repetitive nature. The economic status of the homeworker, stemming from her structural position in the economy, has little or nothing in common with the independent craftsman working in his own home before the onset of industrialisation. Homeworkers work without supervision and the employer passes judgement only on the finished product. They have no real contact with the economic sphere, generally meeting the employer or the sub-contractor only when collecting or returning work.

This volume is an analysis of the economic and social position of the predominantly female labour force of the homework industries from 1850 to 1985 . We have set the discussion of homeworkers in the context of the changing socio-economic status of women during this period. The type of work women have been able to do and the wages they could and can expect are constrained not only by material factors but also by the prevailing ideology. The nineteenth-century view that a 'woman's place is in the home' meant that women who wished to work, or more often those who had to work, were extremely limited in their choice of employment. This situation has continued through the twentieth century to the present day.

One way that married women could earn money and not contradict the assumptions about their domestic role was to take in homework. A study of homework illustrates the fallacy of the belief that the working class has ever existed on a family wage earned by the male breadwinner. The Industrial Revolution transformed the 
work of women and created the division between home and work. This meant that problems of childcare and domestic responsibilities arose when married women tried to engage in paid employment outside the home. Many of them had to make ends meet by taking in lodgers, housecleaning for others, charring, child-minding or taking in homework.

The homework labour force was recruited from a cross-section of the female population. Lower-middle-class girls did homework as a repectable way of earning money before marriage, and many continued this as a clandestine occupation after marriage. In the countryside large numbers of single and married women worked in the rural home industries, and in the urban centres married women, unmarried mothers, single parents and widows might all take in homework at some time in their lives. Today, the composition of the homework labour force is slightly different but many of the reasons for choosing homework remain unchanged. Women need to earn money and yet are often confined to the home by domestic commitments.

This book looks at the composition of the homework labour force throughout our period and also at the alternatives open to women and how these have changed. The industries employing homeworkers in the period 1850-1914 were many and varied, and were distributed all over the country. We take a detailed look at the work processes involved in some of the most important of these industries, for example glove-, boot- and shoe-making, lacemaking, straw plaiting and sack making. The tailoring industry, which was one of the largest employers of homeworkers, is discussed in detail. There have been some attempts over the years to improve the situation of homeworkers either by organising them into unions or by legislation and we critically evaluate these attempts. After the widespread concern about homeworking in the early twentieth century, it almost appeared as if homework had died out and very little was heard about it in the inter-war or post-Second World War periods. There was a revival of interest in homework in the mid-1970s and researchers found that very little had changed for this 'hidden workforce'. Relatively little has been written about homeworkers, and material relating to this group of workers is sparse. Documentary material has been supplemented in this work by the use of oral evidence from women who were themselves homeworkers. In this way, it was possible to get some idea of how 
Preface xi

women fitted in their waged work with their unpaid domestic responsibilities.

Shelley Pennington

Belinda Westover 